\title{
Pengaruh Penetapan Harga Terhadap Keputusan Pembelian Pada Toko Grosir Herbal Di Pondok Aren, Tangerang Selatan
}

\author{
Agung Tri Putranto ${ }^{1}$ Heni Rusmiati ${ }^{2}$ \\ Universitas Pamulang, agung.tputranto@gmail.com
}

\begin{abstract}
Abstrak. Penelitian ini bertujuan untuk mengetahui apakah terdapat pengaruh penetapan harga terhadap keputusan pembelian pada Toko Grosir Herbal di Pondok Aren-Tangerang Selatan.

Metode penelitian yang digunakan adalah metode penelitian deskriptif assosiatif dengan pendekatan kuantitatif. Jumlah populasi yang ada sebanyak 518 orang, maka peneliti menggunakan rumus slovin untuk menentukan sampel, dengan nilai $\mathrm{e}=0,1$ maka diperoleh jumlah sampel sebanyak 84 orang. Sampel yang diambil berdasarkan teknik sampel acak.Pengumpulan data dengan cara observasi dan penyebaran angket kuesioner. Metode analisis data yang digunakan adalah uji validias, uji reliabilitas, uji regresi linier sederhana, analisis koefisien korelasi pearson ( $r$ ), analisis koefisien determinasi, dan uji signifikansi koefisien (uji t).

Hasil analisis didapat bahwa harga dan keputusan pembelian mendapat respon yang baik dari pelanggan dan perhitungan regresi linier sederhana pada variabel Penetapan Harga $(X)$ dan Keputusan Pembelian $(Y)$ diperoleh hasil $Y=24,86+0,393 X$ yang artinya hubungan positif antara Penetapan Harga terhadap Keputusan Pembelian dengan nilai regresi sebesar 0,393. Nilai koefisien korelasi ( $r$ ) diperoleh rsebesar 0,503 , maka apabila dilihat dari tabel interpretasi koefisien korelasi masuk pada interval 0,40-0,599 dengan tingkat hubungan sedang . Kontribusi variabel $X$ Penetapan Harga terhadap Variabel Y Keputusan Pembelian adalah sebesar $25,30 \%$ sedangkan sisanya sebesar $74.70 \%$ dipengaruhi oleh faktor lain yang tidak diteliti. Berdasarkan hasil pengujian hipotesis menggunakan uji statistik $t$ hitung diperoleh : $t$ hitung $>t$ tabel yaitu 5,20>1,99 yang artinya bahwa Ho ditolak dan Ha diterima, berarti terdapat pengaruh yang positif dan signifikan antara penetapan harga terhadap keputusan pembelian pada Toko Grosir Herbal di Pondok Aren-Tangerang Selatan.
\end{abstract}

\section{Keywords: Penetapan Harga; Keputusan Pembelian}

Abstract. The research aims to determine whether there is a pricing influence on purchasing decisions on Herbal Wholesale stores in Pondok Aren-South Tangerang.

The research method used is a method of descriptive associative research with a quantitative approach. There were a total population of 518 people, then the researcher used the formula Slovin to determine the sample, with the value $E=0.1$ then obtained the number of samples as many as 84 people. Samples were taken based on a randomized sample technique. Collection of data by observation and dissemination of questionnaire poll. The data analysis methods used are Validias test, reliability test, simple linear regression test, analysis of Pearson correlation coefficient $(R)$, coefficient of determination analysis and coefficient of significance test (T-Test).

The results of the analysis were obtained that the price and purchase decision received a good response from the customer and simple linear regression calculations in the pricing $(X)$ variable and the purchase decision $(Y)$ obtained the result $Y=24.86+0,393 X$ which means the relationship Between pricing and purchase decisions with a regression value of 0.393 . The value of the correlation coefficient $(r)$ is derived from 0.503, when viewed from the interpretation table of the correlation coefficient in the $0.40-0.599$ intervals with moderate relationship levels. Variable contribution $X$ price determination to variable $Y$ Purchasing decision is $25.30 \%$ while the remaining $74.70 \%$ is influenced by other factors that are not researched. Based on the results of the hypothesis testing using the calculated T-Statistic test is obtained: T count > T table i.e 5,20 > 1.99 which means that Ho is rejected 
and $\mathrm{Ha}$ accepted, meaning there is a positive and significant influence between pricing to the decision Purchase at the Herbal Wholesale store in Pondok Aren-South Tangerang.

Key words : pricing; purchase decisions

\section{A. PENDAHULUAN}

Toko Grosir Herbal yang beralamat di Jombang Raya 6 No.9A Bintaro Sektor IX Parigi, Kecamatan Pondok Aren, Kota Tangerang Selatan ini adalah salah satu Grosir yang menyediakan produk-produk kesehatan dan obat-obatan herbal, produk yang di pasarkannyapun cukup banyak variannya. Menyedari bahawa persaingan di kalangan syarikat serupa semakin tinggi, syarikat perlu memberi perhatian lebih kepada faktor-faktor yang menyebabkan perubahan harga. Berdasarkan lini perniagaan syarikat, produk herba, matlamat harga syarikat berorientasikan kepada volum tertentu atau yang lazim dikenali sebagai objektif penentuan harga volum. Harga ditetapkan sedemikian rupa untuk mencapai nilai jualan sasaran (Rp). Harga sebenarnya agak rumit dan sukar, jadi kita memerlukan pendekatan yang sistematik yang melibatkan penetapan matlamat dan membangun struktur harga yang sesuai. Pengguna menimbang harga dengan mengukur persepsi nilai menggunakan produk, jika harga melebihi jumlah nilai, pengguna tidak membeli produk. Pengguna juga membandingkan harga produk dengan harga produk yang bersaing“.

Berdasarkan latar belakang masalah di atas, penulis sangat berminat dalam menjalankan penyelidikan dengan tajuk: Kesan Harga Keputusan Membeli di Toko Borong Herbal di Pondok Aren - Tangerang Selatan

Berdasarkan latar belakang, pengenalan masalah dan had masalah, masalah berikut dapat dirumuskan: 1. Bagaimana penetapan harga pada Toko Grosir Herbal di Pondok ArenTangerang Selatan? 2. Bagaimana keputusan pembelian pada Toko Grosir Herbal di Pondok Aren-Tangerang Selatan? 3.Berapakah pengaruh harga pembelian keputusan pembelian pada Toko Grosir Herbal di Pondok Aren-Tangerang Selatan.

Objektif yang akan dicapai dari kajian ini adalah : 1. Untuk mengeetahui penetapan harga pada Toko Grosir Herbal di Pondok Aren-Tangerang Selatan. 2. Untuk mengetahui keputusan pembelian pada Toko Grosir Herbal di Pondok Aren-Tangerang Selatan. 3. Untuk mengetahui seberaapa beesar pengaruhpenetapan harga teerhadap kepuutusan pembeliian pada Toko Grosir Herbal di Pondok Aren Tangerang Selatan.

\section{B. KAJIAN LITERATUR}

Harga

Menurut Kotler \& Keller (2018: 67) harga adalah satu elemen campuran pemasaran yang menjana pendapatan, elemen lain menjana kos. Harga adalah elemen paling mudah dalam proses pemasaran untuk menyesuaikan: ciri produk, saluran dan komunikasi bahkan memerlukan lebih banyak masa. Berdasarkan pendapat ahli-ahli di atas, disimpulkan bahawa harga adalah nilai (biasanya dinyatakan dalam bentuk wang) yang mesti dikorbankan untuk dapat memiliki, menggunakan atau menggunakan item dan perkhidmatan untuk mendapatkan kepuasan. Oleh itu, dapat disimpulkan jika harganya sangat tinggi, pengguna biasanya mengharapkan kualiti yang tinggi, dan persepsi sebenar mereka akan dipengaruhi oleh harapan ini. Jika harga terlalu tinggi, organisasi dianggap tidak jahil terhadap pelanggan, atau dianggap penipuan. Sebaliknya, jika harga terlalu rendah, pelanggan dapat meragui kemampuan organisasi dari segi kualiti perkhidmatan. 
Keputusan Pembelian

Menurut keputusan pembelian Tjiptono (2015: 39) adalah tindakan individu secara langsung atau tidak langsung terlibat dalam usaha memperoleh dan menggunakan produk atau perkhidmatan yang diperlukan. Walaupun Kotler \& Armstrong (2016: 177) mentakrifkan keputusan pembelian sebagai sebahagian daripada tingkah laku pengguna. Tingkah laku pengguna adalah kajian bagaimana individu, kumpulan, dan organisasi memilih, membeli, menggunakan, dan bagaimana barangan, perkhidmatan, idea atau pengalaman memenuhi kehendak dan keinginan mereka.

Kerangka Pemikiran

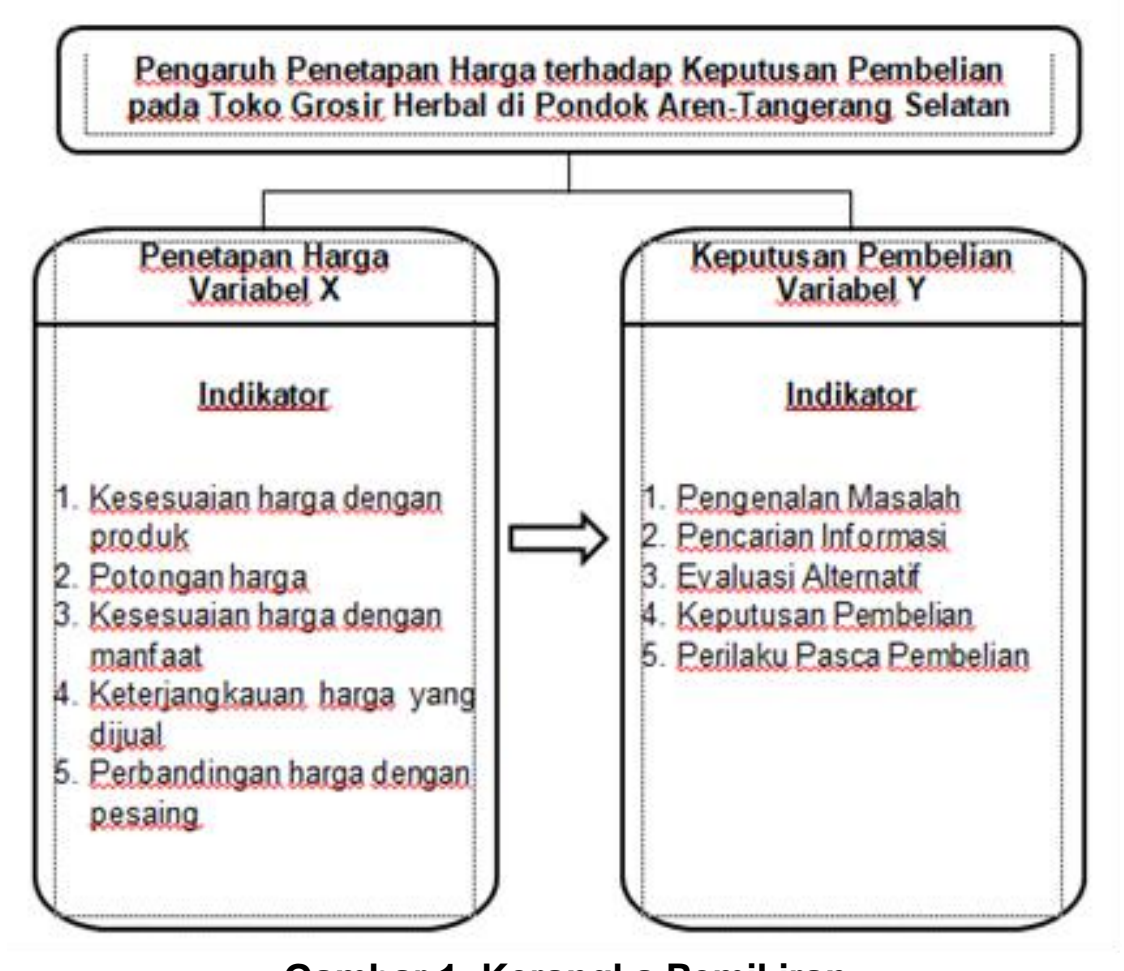

Gambar 1. Kerangka Pemikiran

\section{METODOLOGI PENELITIAN}

"Objek kajian ini dijalankan di Kedai Borong Herbal yang terletak di Jalan Jombang Raya 6 No.9A Sektor Bintaro IX Parigi, Daerah Pondok Aren, Bandar Tangerang Selatan. Kajian ini dijalankan selama 5 (lima) bulan bermula dari Disember 2018 hingga April 2019“.

"Jenis kajian ini menggunakan kaedah penyelidikan deskriptif bersekutu dengan pendekatan kuantitatif. Menurut Sugiyono (2017: 35) kaedah deskriptif adalah satu kaedah yang digunakan untuk menggambarkan masalah mengenai persoalan kewujudan pembolehubah bebas, sama ada hanya pada satu atau lebih pembolehubah (pembolehubah yang berdiri sendiri). Walaupun kaedah bersekutu adalah formula penyelidikan yang menanyakan tentang hubungan antara dua atau lebih variabel (Sugiyono, 2017: 37) “.

"Dalam kajian ini, penyelidik mengambil teknik pensampelan kebarangkalian, yang merupakan teknik pensampelan yang memberikan peluang yang sama bagi setiap elemen (anggota) populasi untuk dipilih sebagai ahli sampel, dengan pendekatan pensampelan rawak sederhana di mana teknik menentukan sampel dan populasi dilakukan secara rawak tanpa memperhatikan strata yang ada dalam populasi (Sugiyono, 2017: 81)." 
ISSN No. (PRINI) 2598-0823, (ONLINE) 2598-2893

\section{HASIL DAN PEMBAHASAN}

Karakteristik Responden

Tabel 1. Data Responden Berdasarkan Jenis Kelamin

\begin{tabular}{|c|c|c|c|}
\hline No. & Jenis Kelamin & Jumlah (orang) & Prosentase \\
\hline 1. & Pria & 56 & $67 \%$ \\
\hline 2. & Wanita & 28 & $33 \%$ \\
\hline \multicolumn{2}{|c|}{ Total } & 84 & $100 \%$ \\
\hline
\end{tabular}

Tabel 2. Data Responden berdasarkan Usia

\begin{tabular}{|c|c|c|c|}
\hline No & Usia & Jumlah (Orang) & Prosentase \\
\hline 1 & 10-20 Tahun & 3 & $3 \%$ \\
\hline 2 & $21-30$ Tahun & 27 & $32 \%$ \\
\hline 3 & 31-40 Tahun & 40 & $48 \%$ \\
\hline 4 & $>41$ Tahun & 14 & $17 \%$ \\
\hline \multicolumn{2}{|c|}{ Total } & 84 & $100 \%$ \\
\hline
\end{tabular}

Tabel 3. Data Responden Berdasarkan Pendidikan

\begin{tabular}{|c|l|c|c|}
\hline No. & \multicolumn{1}{|c|}{ Pendidikan } & Jumlah (Orang) & Prosentase \\
\hline 1. & SD & 1 & $1 \%$ \\
\hline 2. & SMP & 4 & $5 \%$ \\
\hline 3. & SMU/SMK & 55 & $65 \%$ \\
\hline 4. & Diploma & 14 & $17 \%$ \\
\hline 5. & Sarjana (S1, S2, S3) & 10 & $12 \%$ \\
\hline \multicolumn{2}{|c|}{ Total } & 84 & $100 \%$ \\
\hline
\end{tabular}


ISSN NO. (PRINT) 2598-0823, (ONLINE) 2598-2893

Tabel 5. Tanggapan Responden terhadap Variabel Penetapan Harga (X)

\begin{tabular}{|c|c|c|c|c|c|c|c|c|c|c|}
\hline \multirow{2}{*}{ No } & \multirow{2}{*}{ Rernyataan } & ss & S & RG & TS & STS & \multirow{2}{*}{ Total } & Total & Rata2 & \multirow{2}{*}{ Ket } \\
\hline & & 5 & 4 & 3 & 2 & 1 & & Skor & Skor & \\
\hline $\mathrm{I}$ & \multicolumn{10}{|c|}{ Kesesuaian harga dengan produk } \\
\hline 1 & $\begin{array}{l}\text { deminan barga acoduk } \\
\text { gcosicherbal sesugj } \\
\text { denganhargayang } \\
\text { teders }\end{array}$ & 18 & 43 & 20 & 3 & 0 & 84 & 328 & 3.90 & $B$ \\
\hline 2 & 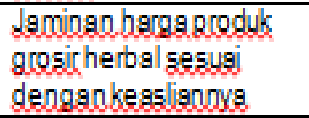 & 24 & 41 & 16 & 3 & 0 & 84 & 338 & 4.02 & $B$ \\
\hline 5 & $F$ & 42 & 84 & 36 & 6 & 0 & 168 & 666 & 3.96 & $\mathrm{~B}$ \\
\hline 2 & $\%$ & $25.0 \%$ & $50.0 \%$ & $21.4 \%$ & $3.57 \%$ & $0.00 \%$ & $100 \%$ & & & \\
\hline II & \multicolumn{10}{|l|}{ Rotongan harga } \\
\hline 3 & 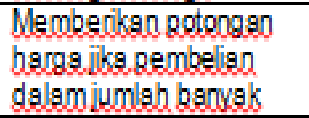 & 20 & 48 & 16 & 0 & 0 & 84 & 340 & 4.05 & $B$ \\
\hline 4 & $\begin{array}{l}\text { Meroberikgn rotongan } \\
\text { barga unctuk setiar } \\
\text { Relanggan }\end{array}$ & 22 & 46 & 13 & 3 & 0 & 84 & 339 & 4.04 & $B$ \\
\hline 5 & $F$ & 42 & 94 & 29 & 3 & 0 & 168 & 679 & 4.04 & $\mathrm{~B}$ \\
\hline 2 & $\%$ & $25.0 \%$ & $44.0 \%$ & $17.3 \%$ & $1.8 \%$ & $0.0 \%$ & $100 \%$ & & & \\
\hline III & \multicolumn{10}{|c|}{ Kesesuaian harga denganmanfaat } \\
\hline 5 & $\begin{array}{l}\text { Harga Rcoduk gcosit } \\
\text { herbal sesus dengaso } \\
\text { manfagt yang diberikgn }\end{array}$ & 15 & 48 & 19 & 2 & 0 & 84 & 328 & 3.90 & $B$ \\
\hline 6 & $\begin{array}{l}\text { Harga Rcoduk gicosit } \\
\text { herbal sangat } \\
\text { menguntungksn yntuk } \\
\text { diual kembali }\end{array}$ & 22 & 39 & 22 & 0 & 1 & 84 & 333 & 3.96 & $B$ \\
\hline 5 & $F$ & 37 & 87 & 41 & 2 & 1 & 168 & 661 & 3.93 & $\mathrm{~B}$ \\
\hline 2 & $\%$ & $22.0 \%$ & $51.8 \%$ & $26.2 \%$ & $1.2 \%$ & $0.6 \%$ & $100 \%$ & & & \\
\hline IV & \multicolumn{10}{|c|}{ Keterjangkayan harga yang dijual } \\
\hline 7 & $\begin{array}{l}\text { Harga lebih efisien dari } \\
\text { barga.89sa }\end{array}$ & 26 & 40 & 15 & 3 & 0 & 84 & 341 & 4.06 & $B$ \\
\hline 8 & 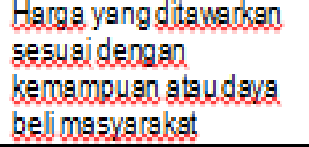 & 23 & 38 & 21 & 1 & 1 & 84 & 333 & 3.96 & $B$ \\
\hline 5 & $F$ & 49 & 78 & 36 & 4 & 1 & 168 & 674 & 4.01 & $\mathrm{~B}$ \\
\hline 2 & $\%$ & $29.2 \%$ & $46.4 \%$ & $21.4 \%$ & $2.4 \%$ & $0.6 \%$ & $100 \%$ & & & \\
\hline $\mathrm{V}$ & \multicolumn{10}{|c|}{ Perhandingan harga dengan pesaing } \\
\hline 9 & $\begin{array}{l}\text { Harga Rcoduk grosic } \\
\text { herbal mampy bersaing } \\
\text { dengan ocod duk sejenis di } \\
\text { tempgt lain }\end{array}$ & 21 & 41 & 22 & 0 & 0 & 84 & 335 & 3.99 & $B$ \\
\hline 10 & 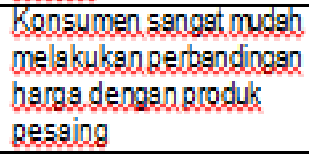 & 28 & 37 & 19 & 0 & 0 & 84 & 345 & 4.11 & $B$ \\
\hline$\Sigma$ & $F$ & 49 & 78 & 41 & 0 & 0 & 168 & 680 & 4.05 & $\mathrm{~B}$ \\
\hline 2 & $\%$ & $29.2 \%$ & $46.4 \%$ & $24.4 \%$ & $0.0 \%$ & $0.0 \%$ & $100 \%$ & & & \\
\hline & dol & 219 & 421 & 183 & 15 & 2 & 840 & & & \\
\hline & Persentase & $26.1 \%$ & $50.1 \%$ & $21.8 \%$ & $1.8 \%$ & $0.2 \%$ & $100 \%$ & Rata2 & 4.00 & $B$ \\
\hline
\end{tabular}

Sumber : Data hasil olahan kuesioner (2019) 
Dari tabel di atas, dapat dilihat jawaban responden pada variabel Penetapan Harga $(X)$ sangat beragam, dapat dijelaskan sebagai berikut:

a. "Daripada 10 kenyataan yang dikemukakan kepada 84 responden, $26.1 \%$ daripada semua responden rata-rata menjawab sangat setuju“.

b. "Daripada 10 item yang dikemukakan kepada 84 responden, $50.1 \%$ daripada responden rata-rata menjawab menjawab“.

c. "Daripada 10 item yang dikemukakan kepada 84 responden, $21.8 \%$ daripada semua responden rata-rata menjawab keraguan“.

d. "Daripada 10 item yang dikemukakan kepada 84 responden, 1.8\% daripada responden rata-rata menjawab tidak bersetuju“.

e. "Daripada 10 item yang dikemukakan kepada 84 responden, $0.2 \%$ daripada semua responden rata-rata menjawab sangat tidak setuju“.

"Dari hasil di atas dapat disimpulkan bahwa Harga di Toko Herbal Pondok Aren-Tangerang Selatan berdasarkan jawaban dari 84 responden dari 10 item dengan skor rata-rata 4.00 dikategorikan BAIK“.

Tabel 6. Tanggapan Responden terhadap Variabel Keputusan Pembelian (Y)

\begin{tabular}{|c|c|c|c|c|c|c|c|c|c|c|}
\hline \multirow[t]{2}{*}{ No. } & \multirow{2}{*}{ Pernyataan } & SS & $\mathbf{S}$ & RG & TS & STS & \multirow[t]{2}{*}{ Total } & \multirow{2}{*}{$\begin{array}{l}\text { Total } \\
\text { Skor }\end{array}$} & \multirow{2}{*}{$\begin{array}{l}\text { Rata } \\
2 \\
\text { Skor }\end{array}$} & \multirow[t]{2}{*}{ Ket } \\
\hline & & 5 & 4 & 3 & 2 & 1 & & & & \\
\hline$I$ & \multicolumn{10}{|l|}{ Pengenalan Masalah } \\
\hline 1 & $\begin{array}{l}\text { Produk Herbal sangat } \\
\text { dibutuhkan }\end{array}$ & 21 & 45 & 18 & 0 & 0 & 84 & 339 & 4.04 & B \\
\hline 2 & $\begin{array}{l}\text { Adanya faktor } \\
\text { lingkungan yang } \\
\text { kurang baik yang } \\
\text { mendorong saya untuk } \\
\text { membeli produk } \\
\text { Herbal }\end{array}$ & 18 & 49 & 17 & 0 & 0 & 84 & 337 & 4.01 & B \\
\hline \multirow{2}{*}{$\Sigma$} & $\mathrm{F}$ & 39 & 94 & 35 & 0 & 0 & 168 & 676 & 4.02 & B \\
\hline & $\%$ & $23.2 \%$ & $56.0 \%$ & $20.8 \%$ & $0.0 \%$ & $0.0 \%$ & $100 \%$ & & & \\
\hline II & \multicolumn{10}{|l|}{ Pencarian Informasi } \\
\hline 3 & $\begin{array}{l}\text { Adanya kebutuhan } \\
\text { akan produk Herbal } \\
\text { membuat saya } \\
\text { berusaha mencari } \\
\text { informasi tentang } \\
\text { produk }\end{array}$ & 24 & 46 & 11 & 3 & 0 & 84 & 343 & 4.08 & B \\
\hline 4 & $\begin{array}{l}\text { Saya mencari } \\
\text { informasi kepada } \\
\text { kawan, dan saudara } \\
\text { yang sudah } \\
\text { menggunakan produk } \\
\text { Grosir Herbal }\end{array}$ & 32 & 36 & 14 & 2 & 0 & 84 & 350 & 4.17 & B \\
\hline \multirow{2}{*}{$\Sigma$} & $\mathrm{F}$ & 56 & 82 & 25 & 5 & 0 & 168 & 693 & 4.13 & B \\
\hline & $\%$ & $33.3 \%$ & $48.8 \%$ & $14.9 \%$ & $3.0 \%$ & $0.0 \%$ & $100 \%$ & & & \\
\hline III & \multicolumn{10}{|l|}{ Evaluasi Alternatif } \\
\hline 5 & $\begin{array}{l}\text { Saya berusaha untuk } \\
\text { mengevaluasi produk }\end{array}$ & 16 & 43 & 23 & 1 & 1 & 84 & 324 & 3.86 & B \\
\hline
\end{tabular}




\begin{tabular}{|c|c|c|c|c|c|c|c|c|c|c|}
\hline & $\begin{array}{l}\text { lain yang ada di } \\
\text { pasaran }\end{array}$ & & & & & & & & & \\
\hline 6 & $\begin{array}{l}\text { Adanya kelebihan } \\
\text { yang ditawarkan dari } \\
\text { produk Grosir Herbal } \\
\text { dibandingkan produk } \\
\text { lain yang sejenis }\end{array}$ & 22 & 41 & 21 & 0 & 0 & 84 & 337 & 4.01 & $\mathrm{~B}$ \\
\hline \multirow{2}{*}{$\Sigma$} & $\mathrm{F}$ & 38 & 84 & 44 & 1 & 1 & 168 & 661 & 3.93 & B \\
\hline & $\%$ & $22.6 \%$ & $50.0 \%$ & $26.2 \%$ & $0.6 \%$ & $0.6 \%$ & $100 \%$ & & & \\
\hline IV & \multicolumn{10}{|c|}{ Keputusan Pembelian (Buying Decision) } \\
\hline 7 & $\begin{array}{l}\text { Karena Harganya } \\
\text { yang relatif jadi saya } \\
\text { memilih produk Grosir } \\
\text { Herbal untuk } \\
\text { memelihara kesehatan }\end{array}$ & 26 & 41 & 17 & 0 & 0 & 84 & 345 & 4.11 & $\mathrm{~B}$ \\
\hline 8 & $\begin{array}{l}\text { Saya memutuskan } \\
\text { untuk membeli produk } \\
\text { Grosir Herbal } \\
\text { berdasarkan } \\
\text { pengalaman orang } \\
\text { lain yang sudah } \\
\text { merasakan manfaat } \\
\text { dan khasiatnya }\end{array}$ & 28 & 40 & 16 & 0 & 0 & 84 & 348 & 4.14 & $\mathrm{~B}$ \\
\hline \multirow{2}{*}{$\Sigma$} & $\mathrm{F}$ & 54 & 81 & 33 & 0 & 0 & 168 & 693 & 4.13 & B \\
\hline & $\%$ & $32.1 \%$ & $48.2 \%$ & $19.6 \%$ & $0.0 \%$ & $0.0 \%$ & $100 \%$ & & & \\
\hline $\mathbf{V}$ & \multicolumn{10}{|c|}{ Keputusan Pasca Pembelian } \\
\hline 9 & $\begin{array}{l}\text { Penggunaan produk } \\
\text { Grosir Herbal } \\
\text { memuaskan, terasa } \\
\text { manfaat dan } \\
\text { khasiatnya maka } \\
\text { saya akan melakukan } \\
\text { pembelian kembali }\end{array}$ & 28 & 42 & 9 & 5 & 0 & 84 & 345 & 4.11 & $\mathrm{~B}$ \\
\hline 10 & $\begin{array}{l}\text { Saya akan loyal } \\
\text { terhadap produk } \\
\text { Grosir Herbal }\end{array}$ & 21 & 45 & 18 & 0 & 0 & 84 & 339 & 4.04 & $\mathrm{~B}$ \\
\hline \multirow{4}{*}{$\Sigma$} & $\mathrm{F}$ & 49 & 87 & 27 & 5 & 0 & 168 & 684 & 4.07 & B \\
\hline & $\%$ & $29.2 \%$ & $51.8 \%$ & $16.1 \%$ & $3.0 \%$ & $0.0 \%$ & $100 \%$ & & & \\
\hline & $\mathrm{Jml}$ & 236 & 428 & 164 & 11 & 1 & 840 & & & \\
\hline & Persentase & $28.1 \%$ & $51.0 \%$ & $19.5 \%$ & $1.3 \%$ & $0.1 \%$ & $100 \%$ & Rata2 & 4.06 & B \\
\hline
\end{tabular}

Sumber : Data hasil olahan kuesioner (2019)

Dari jadual 4.8 di atas, dapat dilihat bahawa jawapan responden kepada pemboleh ubah keputusan pembelian (Y) sangat pelbagai, boleh dijelaskan seperti berikut":

a. "Daripada 10 item yang dikemukakan kepada 84 responden, $28.1 \%$ daripada semua responden rata-rata menjawab sangat setuju.

b. Daripada 10 item yang dikemukakan kepada 84 responden, 51.0\% daripada semua responden rata-rata menjawab bersetuju“.

c. "Daripada 10 kenyataan yang dikemukakan kepada 84 responden, $19.5 \%$ daripada responden rata-rata menjawab keraguan" 
d. "Daripada 10 kenyataan yang dikemukakan kepada 84 responden, 1.3\% daripada responden rata-rata menjawab tidak bersetuju“.

e. "Daripada 10 item yang dikemukakan kepada 84 responden, $0.1 \%$ daripada semua responden rata-rata menjawab sangat tidak setuju.

Dari hasil di atas dapat disimpulkan bahwa Keputusan Pembelian di Toko Herbal Pondok Aren-Tangerang Selatan berdasarkan jawaban responden sebanyak 84 responden dari 10 pernyataan dengan skor rata-rata 4.06 dikategorikan BAIK".

Uji Validitas Variabel Penetapan Harga

Tabel 7. Hasil Perhitungan Validitas Penetapan Harga (X)

\begin{tabular}{|c|c|c|c|}
\hline No. & $\boldsymbol{r}_{\text {hitung }}$ & $\boldsymbol{r}_{\text {tabel }}$ & Keputusan \\
\hline 01. & 0,583 & 0,215 & Valiid \\
\hline 02. & 0,347 & 0,215 & Valiid \\
\hline 03. & 0,503 & 0,215 & Valiid \\
\hline 04. & 0,541 & 0,215 & Valiid \\
\hline 05. & 0,572 & 0,215 & Valiid \\
\hline 06. & 0,479 & 0,215 & Valiid \\
\hline 07. & 0,537 & 0,215 & Valiid \\
\hline 08. & 0,265 & 0,215 & Valiid \\
\hline 09. & 0,353 & 0,215 & Valliid \\
\hline 10 & 0,425 & 0,215 & Valiid \\
\hline
\end{tabular}

Sumber: Data hasil olahan kuesioner (2019)

Berdasarkan keputusan ujian kesahihan instrumen Variabel $X$ dalam jadual di atas, menunjukkan bahawa semua item mempunyai nilai koefisien korelasi (ritung) nilai lebih besar daripada rtable $=0.215$ yang bermaksud item pernyataan diisytiharkan sah.

Tabel 8. Hasil Perhitungan Validitas Keputusan Pembelian (Y)

\begin{tabular}{|c|c|c|c|}
\hline No. & $\boldsymbol{r}_{\text {hitung }}$ & $r_{\text {tabel }}$ & Keputusan \\
\hline 01. & 0,373 & 0,215 & Yaljid \\
\hline 02. & 0,346 & 0,215 & Valiid \\
\hline 03. & 0,239 & 0,215 & Valiid \\
\hline 04. & 0,413 & 0,215 & Valiid \\
\hline 05. & 0,371 & 0,215 & Valiid \\
\hline 06. & 0,418 & 0,215 & Valiid \\
\hline 07. & 0,338 & 0,215 & Valiid \\
\hline 08. & 0,364 & 0,215 & Valiid \\
\hline 09. & 0,461 & 0,215 & Yaljid \\
\hline 10 & 0,367 & 0,215 & Valiid \\
\hline
\end{tabular}

Berdasarkan keputusan ujian kesahihan instrumen Variabel $Y$ dalam jadual di atas, menunjukkan bahawa semua item mempunyai nilai koefisien korelasi (ritung) nilai lebih besar daripada rtable $=0.215$ yang bermaksud item pernyataan diisytiharkan sah 
Uji Reliabilitas Variable Penetapan Harga (X)

$0.579 \geq 0.215$

Uji Reliabilitas Variabel Keputusan Pembelian (Y)

$0.297 \geq 0.215$

Uji Regresi Linier Sederhana

Hasil diperoleh persamaan berdasarkan pekali output adalah $Y=24.86+0.393 X$ yang artinya perubahan $Y$ adalah selaras dengan perubahan dalam $X$. Maka nilai $Y$ akan meningkat jika $X$ meningkat, jika tidak, nilai $Y$ akan berkurang jika $X$ berkurang. Oleh itu, dapat disimpulkan bahawa harga mempunyai kesan positif terhadap keputusan pembelian, dan sebaliknya. Pekali regresi $X=0.393$, skor pembolehubah $Y$ akan meningkat sebanyak 1 unit dengan mengandaikan 24.86 unit tetap

Uji Koefisien Korelasi

Dari koefisien korelasi di atas data analisis diperoleh $r=0.503$ atau nilai $r$ positif, yang bermaksud terdapat korelasi antara Penetapan Harga (X) dengan Keputusan Pembelian ( $\mathrm{Y}$ ) di Toko Herbal Pondok Aren di Tangerang Selatan yang sama dengan 0.503.

Uji Koefisien Determinasi

Dari hasil perhitungan koefisien penentuan di atas dapat disimpulkan bahwa, Keputusan Pembelian ( $Y$ ) dipengaruhi oleh Harga $(X)$ sebesar $25,30 \%$ dan sisanya $74,70 \%$ dipengaruhi oleh faktor lain yang tidak diperiksa.

Pengujian Hipotesis (Uji t)

Dari pengiraan ujian hipotesis di atas dapat dilihat bahawa t hitung $t \geq t$ adalah $5.20 \geq 1.99$ yang bermaksud terdapat pengaruh positif dan signifikan antara Penetapan Harga Keputusan Pembelian di Toko Borong Herbal di Pondok Aren-Tangerang Selatan. Jadi para penyelidik menetapkan hipotesis dalam kajian ini adalah $\mathrm{Ha}: \mathrm{p} \neq 0$, terdapat pengaruh signifikan antara Harga pada Keputusan Pembelian di Toko Borong Herbal di Pondok Aren, Tangerang Selatan, Ho ditolak dan Ha diterima

\section{E. KESIMPULAN}

Kesimpulan dari hasil analisis dan pembahasan mengenai kesan penetapan harga terhadap keputusan pembelian pada Toko Bendi Herbal di Pondok Aren-Tangerang Selatan, beberapa kesimpulan dapat diambil sebagai berikut : 1. Penetapan Harga yang diterapkan pada Toko Grosir Herbal di Pondok Aren-Tangerang Selatan, dari 84 responden dengan 10 pernyataan dengan rata-rata skor 4,00 dikategorikan BAIK. 2. Keputusan Pembelian pada Toko Grosir Herbal di Pondok Aren-Tangerang Selatan mendapat respon yang beragam dari 84 responden dengan 10 pernyataan dengan rata-rata skor 4,06 dikategorikan BAIK. 3.Terdapat pengaruh positif antara Penetapan Harga terhadap Keputusan Pembelian dengan nilai regresi sebesar 0,393 . Nilai koefisien korelasi ( $r$ ) sebesar 0,503 , artinya variabel penetapan harga memiliki hubungan yang sedang namun cukup signifikan. Kontribusi variabel $X$ Penetapan Harga terhadap Variabel Y Keputusan Pembelian adalah sebesar $25,30 \%$ sedangkan sisanya sebesar $74.70 \%$ dipengaruhi oleh faktor lain yang tidak diteliti. 
Berdasarkan hasil pengujian hipotesis menggunakan uji statistik t hitung diperoleh : $t$ hitung $>$ ttabel yaitu 5,20>1,99 yang artinya bahwa Ho ditolak dan Ha diterima, berarti terdapat pengaruh yang positif dan signifikan antara penetapan harga terhadap keputusan pembelian pada Toko Grosir Herbal di Pondok Aren-Tangerang Selatan.

\section{DAFTAR PUSTAKA}

Abubakar, Rusydi. 2017. Manajemen Pemasaran. Bandung: CV. Alfabeta.

Alma, Buchori. 2014. Manajemen Pemasaran \& Pemasaran Jasa. Bandung: CV. Alfabeta.

Arikunto, Suharsimi. 2014. Prosedur Penelitian Suatu Pendekatan Praktek. Jakarta: PT. Rineka Cipta.

Hasibuan, Malayu. 2018. Manajemen Dasar, Pengertian, dan Masalah. Jakarta: PT Bumi Aksara.

Kotler, Philip dan Kevin Keller Lane. 2018. Manajemen Pemasaran Edisi 13 Jilid 1 dan 2. Jakarta: Erlangga.

Kotler, Philip dan Garry Amstrong. 2012. Prinsip - prinsip Pemasaran Edisi 13. Jilid 1. Jakarta: Erlangga.

Kotler, Philip dan Garry Amstrong. 2014. Principle of Marketing ,15th edition. New Jersey: Pearson Prentice Hall.

Kotler, Philip dan Garry Amstrong. 2016. Prinsip - prinsip Pemasaran Edisi 13. Jilid 2. Jakarta: Erlangga.

Lupiyoadi, Rambat. 2014. Manajemen Pemasaran Jasa Edisi 3. Jakarta : Salemba Empat.

Mursid. 2017. Manajemen Pemasaran. Jakarta: PT. Bumi Aksara

Sarwono, Jonathan. 2014. Metode Penelitian Kualitatif dan Kuantitatif. Yogyakarta: Graha Ilmu.

Stoner, A.F. 2014.Manajemen. Jakarta : Erlangga.

Sugiyono. 2017. Metode Penelitian Kuantitatif, Kualitatif dan R \& D. Bandung: CV. Alfabeta.

Supangat, Andi. 2010. Statistika Dalam Kajian Deskriptif, Intferensi, dan Nonparametik. Jakarta: Kencana.

Swastha, Bashu dan Handoko. 2010. Manajemen Pemasaran Edisi Pertama Cetakan Ketiga. Yogyakarta: BPFE.

Terry, George R. 2010. Dasar - Dasar Manajemen Cetakan kesebelas. Jakarta: Bumi Aksara. Tjiptono, Fandy. 2015. Strategi Pemasaran edisi 4. Yogyakarta: Andi. 